\title{
The Impact of Foreign Direct Investment on Gross Domestic Product in Iraq During the Period (2006 - 2015)
}

\author{
Shivan Hadi Ali ${ }^{1}$, Shivan Abdulrahman Jameel ${ }^{2}$ \\ 1,2 College of Administration \& Economics, University of Duhok, Kurdistan-region, Iraq
}

\begin{abstract}
The paper aims at examining the impact of Foreign Direct Investment on Gross Domestic Product in Iraq over the period 20062015. Data have been collected from the World Bank database. For the purpose of analyzing data, the study applied Foreign Direct Investment (FDI) Net Inflows as an independent variable while Gross Domestic Product (GDP) as a proxy for economic growth as a dependent variable. The results of the study found that all of the variables under study are non-stationary at the level while stationary at first differenced by utilizing unit-root tests (ADF). The findings of Johansen Test for Co-integration showed that there is no long-term relationship among variables. Other findings of the paper revealed that, in short term, it is concluded that FDI Granger-Causes GDP and there is a short-run causality running from FDI to GDP. The research recommended that Iraq has to pay more attention to improve the level of education sectors and financial sector and to empower human capital. It also has to decrease lending rate, transportation and instability terms of political and economic environment as well as to improve liberalized market environment.
\end{abstract}

Keywords: Foreign Direct Investment, Gross Domestic Product, Co-integration, Granger Causality.

\section{INTRODUCTION}

\subsection{Background of the study}

The fifth edition of the IMF's Balance of Payments Manual (BPM5) defines FDI as "a category of international investment that reflects the objective of a resident in one economy (the direct investor) obtaining a lasting interest in an enterprise resident in another economy (the direct investment enterprise)". The lasting interest entails the existence of a long-term relationship between the direct investor and the direct investment enterprise, and a significant degree of influence by the investor on the management of the enterprise. A direct investment relationship is established when the direct investor has obtained 10 percent or more of the ordinary shares or voting power of an enterprise abroad (Carson, 2003).

IMF defines FDI as the acquirement of at least ten percent of the ordinary shares or voting power in a public or private enterprise by nonresident investors. Direct investment engages a lasting interest in the management of an enterprise and includes reinvestment of profit.

Nowadays, the world is witnessing the considerable impact of globalization which has completely redefined the way in which business used to be operated. One of the key results of globalization is that there has been an enormous growth in global FDI. This impressive development has taken place simultaneously with a significant growth in international trade. The term 'Global Village' was invented to indicate that the distance is no longer a constraint and the trade boundaries have become blurred. FDI is a crucial factor in the globalization process as it intensifies the interaction between states, regions and corporations. Growing international flows of portfolio and direct investment, international trade are all parts of this process. Globalization offers an extraordinary opportunity for developing countries to achieve faster economic growth through trade and investment. During 1970s, international trade grew more rapidly than FDI, and thus international trade was by far than most other important international economic activities. This situation changed significantly in the middle of the 1980s, when world FDI started to increase sharply. In this period, the world FDI has augmented its importance by 
transferring technologies and establishing marketing and procuring networks for efficient production and sales internationally (Urata, 1998). The huge increase in the volume of FDI during the last two decades provides a strong support for research on this phenomenon.

After the global financial crisis, the status and importance of Asian economies have increased a lot because of their more than expected flexibility to financial crisis. Asian economies are expanding quickly and their growing clout can be felt from the fact that out of top 5 economies of the world (in terms of GDP by PPP) 3 are Asian (Agrawal and Khan, 2011). Finally, it is also crucial to define Gross domestic product (GDP) that is the monetary value of all the finished goods and services produced within a country's borders in a specific time period. Though GDP is usually calculated on yearly, it can be calculated quarterly as well (in the United States, for example, the government releases an annualized GDP estimate for each quarter and also for an entire year). GDP includes all private and public consumption, government outlays, investments, private inventories, paid-in construction costs and the foreign balance of trade (exports are added, imports are subtracted). Concisely, GDP is a broad measurement of a nation's overall economic activity - the godfather of the indicator world (Investopedia.com)

In conclusion, the role of foreign direct investment (FDI) in the growth process has for long been a topic of intense debate. Although this debate has provided rich insights into the relationship between FDI and growth, there is very little empirical analysis of the issue, partly because of the lack of a conceptual design and a succinct testable hypothesis (Agrawal and Khan, 2011). Present study attempts to examine the impact of FDI on GDP of Iraq. In second part of the research the relationship between GDP and FDI has been established with the support of literature review. In the third part the previous works done on this and related topics have been explored by providing a methodology. Fourth part contains data source, discussion as well as the findings of the tests applied and their discussion used in this paper and at last fifth part ends our discussion by concluding the whole essence of the paper.

\subsection{Research Problem:}

The flow of Foreign Direct Investment is considered the main factor that affects a country's economy (Ahmed \& Malik, 2012). The Iraqi economy like other developing economies suffers from lack of domestic savings; therefore, Foreign Direct Investment considered as an alternative to fill the domestic savings gab by supplying the needed capital which can boost the growth level of real domestic product. Given the evidence of other developing nations, (FDI) can help the economy in creating more jobs, and bringing in new production techniques that might lead to more exports of goods and services, and supplying the economy with the needed foreign exchange, and optimal utilization of domestic economic resources. Unexpectedly, the empirical studies which have examined the impact of (FDI) in developing countries brought a contradictory view. In one hand, several studies found positive relationship between (FDI) and economic growth. While on the other hand, some other studies revealed a negative effect of (FDI) on economic growth (Abu - Eideh, 2014). Finally, it is worth mentioning that the empirical correlation between FDI and Economic Growth is still ambiguous in Iraq due to the lack of empirical studies conducted in the literature; this might go back to the fact that Foreign Investments were unavailable in Iraq before 2003 (Asaad, 2014). The problem of the present study is set to bring an empirical analysis to the relationship between Foreign Direct Investment (FDI) and Gross Domestic Product (GDP) in Iraq during the time period of $2006-2015$.

\subsection{Research Questions:}

This research attempts to answer the following 
questions:

- What are the concepts of Foreign Direct Investment and Gross Domestic Product?

- To what extent does FDI affect Iraqi GDP?

- What is the nature of the relationship between FDI and GDP?

- Which variable under study granger-causes the other?

\subsection{Research Objectives:}

- To explain the concepts of Foreign Direct Investment and Gross Domestic Product.

- To investigate how FDI affects the Iraqi GDP.

- To identify the relationship between FDI and GDP in Iraq.

- To determine the granger causality between the two variables under study.

\subsection{Research Hypothesis}

After reviewing the literature, the current study addresses the following hypotheses:

A null and alternative hypothesis will be taken for the above-mentioned regression equation, once the significance of the equation is checked.

\section{i. Hypothesis 1:}

Null Hypothesis $\left(H_{0}\right): \boldsymbol{\beta}_{\mathbf{1}}=0$ (implying that Foreign Direct Investment does not have a statistically significant impact on Gross Domestic Product)

Alternative Hypothesis $\left(H_{1}\right): \boldsymbol{\beta}_{\mathbf{1}} \neq 0$ (implying that Foreign Direct Investment has a statistically significant impact on Gross Domestic Product)

\section{ii. Hypothesis 2:}

Null Hypothesis $\left(H_{0}\right)$ : FDI has a "positive effect" on GDP in Iraq.

Alternative Hypothesis $\left(H_{1}\right)$ : FDI has a "negative effect" on GDP in Iraq.

\subsection{Research Significance}

The existence of foreign firms in the economy with their superior endowments of technology and management skills will introduce local firms to fierce competition (Chen, Chang, \& Zhang, 1995). Local firms may also be obliged to develop their performance and to invest in research and development (R\&D). Thus FDI promotes the marginal productivity of the capital stock in the host economies and thereby promote growth (Wang \& Blomstrom, 1992). Moreover, Lahiri and Ono (1998) revealed that higher efficiency of foreign firms may help reduce prices and hence increase consumers' surplus. Consequently, FDI raises employment by either creating new jobs directly or using local inputs (thus creating more jobs indirectly). Finally, as can be seen from literature that FDI is an important indicator that could affect Gross Domestic Product positively and improve it especially in developing countries including Iraq; therefore, it is fundamentally important for the country to bring a friendly atmosphere for foreigners to invest their capital in a host country and enhance its GDP.

\section{LITERATURE REVIEW}

This research presents some of the previous studies about the impact of Foreign Direct Investment on Gross Domestic Product. The literature review also covers the importance of FDI in Iraq and prospects of doing business in Iraq.

\subsection{Foreign Direct Investment in Iraq:}

In last decade in 2006, the Iraqi Federal Government approved the Investment Law No. 13 (Federal Investment Law) which presents the foundation for attracting foreign investment into Iraq. The Federal Investment Law was modified in 2009 to embrace foreign land ownership rights in relation to a foreign company's investment, and it is understood that there are currently additional discussions in progress in regards to additional enhancements of the investment regime. Several strategic initiatives including tax incentives, investor guarantees and obligations of investors have been provided by The Federal Investment Law. Additionally, the Law established the National Investment Commission (NIC), a body that oversees projects at federal and strategic level. The 
NIC aims at operating as a one-stop-shop to represent Iraq's single point of contact for investors interested in doing business there. The NIC is responsible for processing applications and issuing investment licenses in a streamlined way, and administering several strategic initiatives such as tax and customs holidays, investor guarantees, and facilitating entry and departure of investor's employees into and out of Iraq. Moreover, it plays a critical role in providing a range of services to investors, including logistical support, business process support and introductions to key networks. The Federal Investment Law has established the Provincial Investment Commission to support the needs and priorities of Iraqi provinces. In this capacity, the NIC generates a clearinghouse to investment queries, and paves the gateway to investments in Federal Iraq (webuildiraq.org).

The inactive Iraqi economy has received a new thrust in recent years. As the country looks forward to combat a prolonged period of conflict and stagnation, economic opportunities have opened up. An amalgamation of several factors makes Iraq a favorable business and investment destination. Some important issues including: the need to build new and modern infrastructures, develop housing, healthcare systems and other public services, enhance human resource through training in market-usable skills, foster expansion of export base, provide a wide range of opportunities to international companies to be ready to take on the challenge of post-war reconstruction. It is believed by some individuals that rebuilding of Iraq offers one of the biggest global investment opportunities in decades, even though continued political chaos and uncertainty makes risky business environment. Nevertheless, a relative improvement in security situation of the country in the last two years with decline in rebellion is helping spur growth. The Iraqi government's Five-Year National Development Plan (2010-2014), proposed as targets a 9.4\% annual rate of economic growth with US\$186 billion worth of investments. Iraq's largely state-owned economy is dominated by the oil sector, which traditionally provides more than $90 \%$ of foreign exchange earnings (Cheema, 2013).

\subsubsection{Iraq Seeks FDI for Reconstruction Projects}

Iraq's National Investment Commission (NIC) has released a list of major and medium-sized strategic projects containing 157 projects seeking foreign investment. Of these, 41 were classed as 'major strategic projects' and the remainder as 'medium-sized projects'. Almost all are located in the relatively peaceful south-east or north-east of Iraq, where Islamic State (IS) has been driven out. The majority of the main projects are within the chemicals, petrochemicals, fertilizers and refinery sector, which like many highvalue industries in Iraq endured significant damage during the past few years. For example, $60 \%$ of the existing fertilizer plant in Baiji is damaged and it is therefore seeking $\$ 500$ million for reconstruction with a stated $17 \%$ return on investment, according to NIC. Iraq's primary destination for inbound green field FDI is in its coal, oil and natural gas sector, which has attracted $\$ 35.39$ billion since January 2003, according to FDI Markets, a green field investment monitor from the Financial Times. The country's chemicals sector is the third highest destination, having garnered \$6.01billion in the same period (Wing, 2013).

However, nowadays Iraq has had difficulty attracting foreign capital due to its substantial security problems, fragile institutions and lack of governance. Nonetheless, hydrocarbons continue to draw in foreign companies, and the majority of FDI goes to the oil industry. Since 2013 the FDI inflow has been negative, reaching -5 billion USD in 2017. Therefore, the total FDI stock declined to USD 10.1 billion, accounting for nearly 5.3\% of GDP (UNCTAD 2018 World Investment Report). In addition to the oil industry, the production of cement and the 
construction \& public works sector provide interesting opportunities for investment. The United States and the European Union are the main investors in Iraq: the stock of FDI from the U.S. was USD 5.91 billion in 2016 (Central Bank of Iraq).

Iraq has long term prospective for foreign investments. In fact, Iraq possesses the fourth largest proven oil reserves in the world and needs major reconstruction efforts and infrastructure development. According to Iraqi law, a foreign investor is entitled to make investments in Iraq on terms no less favorable than those applicable to an Iraqi investor, and the amount of foreign participation is unlimited. Although, Iraq's National Investment Law limits foreign direct and indirect ownership of natural resources, particularly the extraction and processing of any natural resources. Further restrictions employ to the ownership of banks and insurance companies. According to the National Investment Law, the Iraqi government reserves the right to screen foreign direct investment. Iraq is making slow progress enacting laws and developing institutions needed to implement economic policies. Furthermore, political reforms are still needed to alleviate investors' concerns regarding the uncertain business climate. Despite the fact that the Iraqi government is eager to attract additional foreign direct investment, it faces several obstacles, including a weak political system and concerns about security and social stability. Corruption, obsolete infrastructure, a lack of skilled labor and outdated commercial laws impede investment and continue to constrain growth of private, non-oil sectors (Lloyds bank, 2019)

\subsubsection{Prospects of doing business in Iraq}

Iraq can be an interesting destination for FDI, as the country still needs investment in reconstruction and infrastructure development. Two of the positive indicators of business opportunities are: (Lloyds bank, 2019)

a. Iraq experienced the lack of capital, technology, and skills for more than two decades due to prolonged sanctions and war. These crucial inputs are needed in one and all sectors of economy as the country rebuilds, and the government recognizes the fact that foreign investors can bring them all. The Iraqi government is eager to diversify the economy away from oil and has steadily opened the market to attract external investment and joint ventures in housing, infrastructure, industry, manufacturing, agriculture, food processing, transportation, financial services and tourism (Lloyd's bank, 2019). To facilitate investment, the National Investment Law 13 (2006) has been modified to allow non-Iraqis to own land for housing projects, as well as investment partnerships with state-owned enterprises. The same Law comprises several exemptions for qualified investments, including a ten-year exemption from taxes and exemptions from import duties for the necessary equipment and materials (Cheema, 2013).

b. In the upcoming years Iraq will have to employ several multi-billion-dollar projects in numerous sectors, like security, energy, environment, construction, healthcare, tourism, agriculture, and infrastructure sectors. Consequently, Investors can repatriate capital brought into Iraq, along with proceeds. Surprisingly, Iraq possesses the world's fourth largest proven oil reserves (Lloyds bank, 2019).

\subsection{Empirical Evidence}

There are some studies that indicated that the relationship between economic growth and FDI is conditioned by other factors like: small technological gap between local companies and foreign firms ( $\mathrm{Li}$ and Liu (2005)), education level (Lipsey (2000)), trade openness (Balasubramanyam et al., 1996, Fitzová and Žídek, 2015), financial development (Alfaro et al., 2004), export diversification (Nicet-Chenaf and Rougier, 2009) and a stable and efficient institutional and legal environment (Bengoa and Sanchez-Robles, 
2003).

An empirical study by Borensztein, Gregorio and Lee (1998) investigated the impact of FDI on economic growth rate in cases of 69 developing countries during the period 1970-1989. The results of this study found a positive relationship between FDI and economic growth only when the host country has satisfactory absorptive competence and high level of educational sectors for progressive technologies. By contrary, a negative impact of FDI on economic growth was indicated by Audi (2011) for seven south Mediterranean countries (Turkey, Jordan, Syria, Algeria, Egypt, Morocco, and Tunisia).

Some studies were empirically conducted for Asian Countries to investigate the impact of FDI on Economic Growth, like: Bende-Nabebde (2001) studies the impact of FDI on economic growth of the ASEAN5 for the period 1970-1996. The paper finds that FDI has a positive significant effect on economic growth for Indonesia, Malaysia, and Philippines, while they identify a negative relationship for Singapore and Thailand. Similarly, Marwah and Tavakoli (2004) find that FDI and economic growth are positively correlated for all four countries. Zhang (2001) demonstrates that the foreign direct investments appear to support China's economic growth. The study also reveals that FDI seems to participate in income growth in China through positive externality effect such as: dispersing technology and facilitating evolution and also via direct effects such as boosting exports and increasing productivity.

Moreover, Su and Liu (2016) stated that FDI and human capital are the vital contributors to economic growth in China; human capital is an initiator for the new technology diffusion embodied in FDI. The study also finds that FDI has a positive effect on the per capita GDP growth rate and this effect is intensified by the human capital endowment of the city. The paper of Chee and Nair (2010) analyses the relationship between FDI, financial sector development and economic growth on a sample of 44 Asia and Oceania countries for the period 1996-2005. The empirical analysis revealed that the positive impact of FDI on economic growth can only be achieved if developing and least developed countries in the Asia-Oceania region invest in financial sector development, education and training and adoption of new technology.

Some of the recent studies are the paper of Jun (2015) investigated the outcomes of FDI on eight SAARC (Afghanistan, Bangladesh, India, Nepal, Maldives, Pakistan, Sri Lanka and Bhutan) member countries during the period 1960- 2013. The Granger causality results indicated bi-directional causal relationships between FDI and real GDP as a whole. Additionally, the basic objective of the paper of Baig et al. (2016) is to compute the long run relationship between FDI and GDP for south ASIAN countries (Pakistan, Nepal, Bhutan, India and Maldives) over the period commencing from 1991 to 2012. The findings of the study by utilising co integration test indicate that there exist co-integration equations at the 0.05 level. The granger test reveals that FDI and GDP in case of Nepal cause a unidirectional causality. The study will support and give guiding principle to policymaker and investor make scheme to bolster economic growth in Pakistan which is suffering from a high ratio of unemployment.

The findings of the paper of Trojette (2016) highlight the role of institutional development in moderating the ambiguous impacts of FDI on GDP growth for the five regions (SSA, MENA, Europe, Asia and America); the researchers find that the index of institutions matter for all groups except for the America group. One of the results of the study for the MENA region revealed that FDI impacts Economic Growth negatively for 5 of the 19 countries in the sample (Algeria, Iraq, Lebanon, Libya and West Bank and Gaza) due to the low level of institutions (below 0.54). This level hinders them from the benefit of FDI on growth; during the period 1984- 
2013, Iraq and Lebanon possessed the lowest level of institutions (0.39 and 0.43 respectively) as a result of high level of corruption and other forms of cronyism. One of the findings of the research conducted by Jude and Levieuge (2014) on a sample of 94 developing countries over the period 1984-2009 confirms a nonlinear positive effect of FDI on economic growth through supporting an institutional development. However, the study finds that FDI alone has a negative or, at best, a non-significant effect on growth. The same results were found by Brahim and Rachdi (2014) for the same purpose for 19 MENA countries during the period commencing from 1984 to 2011. The study of Gupta and Singh (2016) in BRICS nations over the period 1992-2013 reveals the higher economic growth in Brazil, China, and India cause of higher Inwards FDI in the long run. On the other hand, the study claimed that there was no co-integration between Inwards FDI and GDP for the Russia and South Africa in the longrun; FDI and GDP are independent of each other. The study of Carlos and Eddie (2015) applied econometric analysis and by employing granger causality test, the research found no causal link between FDI and GDP for: Brazil, Mexico, Peru and South Korea. The paper only found result for China and revealed causality between the two variables which is contrary to the predicted direction which means running from GDP to FDI and not vice versa. Besides, the researchers showed a little relationship between variables because of the fact that FDI, as a percentage of total gross fixed capital formation (GFCF), is so small that it has only a marginal influence in economic growth.

Empirical evidence from 23 African countries by Seyoum et al. (2015) portrayed two-way Granger causality link between FDI and economic growth. However, the researchers reveal that this causal link is not homogeneous among individual countries in their sample. More specifically, the paper indicates unidirectional causality from FDI to GDP growth in three countries (Egypt, Gabon, and Mauritania), whereas they found unidirectional causality from the opposite direction in four countries (Cote d'Ivoire, Kenya, South Africa and Zambia). The result of the study of Ozturk and Kalyoncu (2007) exhibits a positive bi-directional causality between FDI and economic growth in case of Turkey whereas there is only economic growth that causes foreign direct investment in case of Pakistan. Baharumshah and Almasaied (2009) show that Malaysian economic growth rates can be affected by FDI, domestic capital formation, financial deepening and human capital. Moreover, it discovers suitably controlling for other drivers of economic growth such as exportation, domestic investment and human capital. According to the study, economic growth is significantly affected by FDI; however, the FDI's effect is less visible than the effect of domestic investment on economic growth.

Another empirical study conducted by Balamurali and Bogahawatte (2004) for Seri Lanka over the period of 1977-2003 exhibits that economic growth rates are significantly affected by FDI; the result also points out that there is bi-directional causality between economic growth and FDI. Besides, it shows that there is a low level of investment in Seri Lanka as a result of several reasons such as low investment of human resource, the low level of growing infrastructure sector, high lending rate, transportation and instability in terms of political environment. Agrawal and Khan (2011) for India and China showed that the economic growth in India is less affected by FDI than China because the later can utilize FDI better than the former. The results of the study of Umoh et al. (2012) for Nigerian Economy suggest that there is a positive two-way causality between growth rate and FDI. Moreover, according to the analysis, the increasing private contribution and superior openness are main causes that can obtain higher economic growth rates and to attract more foreign direct investments to flow into Nigeria.

It is important to mention that another empirical study 
conducted by Arisoy (2012) for Turkish economy explore that FDI positively participates in economic growth rate and total factor productivities through technological spillovers and capital accumulations. Within a new growth framework, Balasubramanyam et al. (1996) for forty-six developing countries over the period 1970-1985 showed support for Bhagwati's hypothesis that FDI will increase growth in countries which adopt export promotion policy. Li and Liu (2005) find positive effect of FDI on economic growth through its interaction with human capital in 84 developing countries, but a negative effect of FDI on economic growth via its interaction with the technology gap.

Bengoa and Sanchez-Robles (2003) for eighteen Latin American reveal that FDI has positive and significant impact on economic growth in the host countries. However, they explore that the benefit to the host country requires adequate human capital, political and economic stability and liberalized market environment. By contrast, the findings of Carkovic and Levine (2005) show that, FDI inflows neither exert influence on economic growth directly nor through their effect on human capital. Choe (2003) for eighty countries finds evidence of Granger causality relationship between FDI and economic growth in two-way direction but with stronger effects visible from economic growth to FDI rather than the opposite. Another recent study conducted by Abdul Khaliq and Noy (2007) for Indonesian economy found that FDI is noticed to have a positive effect on economic growth. However, when accounting for the different average growth performance across sectors, the beneficial impact of FDI is no longer obvious. In Addition, another recent research conducted by Aga (2014) for Turkey shows that there is no causality linkage between GDP with both FDI and DIN. At the same time, there is one-way causality between GDP and trade liberalisation (TL) in the context of Turkey. On the other hand, it is found that there is statistically insignificant yet positive short run impact of foreign direct investment on gross domestic product (GDP) in Turkey.

Finally, some of the studies have been conducted in the literature for European Countries including the study by Acaravci and Ozturk (2012) which provide a survey of the literature on FDI, export and growth, and empirically investigates the causal relationship between economic growth, export and FDI for the ten transition European countries (Bulgaria, Czech Republic, Estonia, Hungary, Latvia, Lithuania, Poland, Romania, Slovak Republic and Slovenia) by using quarterly data from 1994 to 2008. The findings of the paper reveal that there is causal relationship between FDI, export and economic growth in four out of ten countries considered. The purpose of the paper of Andraz and Rodrigues (2010) is to analyze possible causal relationships between exports, inward foreign investment and economic growth in Portugal and identify their direction. The results portrayed a positive relationship between FDI, Exports and Economic Growth in the long-run using data from 1977 to 2004 in Portugal, while, in the short run it found a bi-directional causality between FDI and Growth. The goal of the research of Simionescu (2016) is to investigate the relationship between economic growth and foreign direct investment inflows in the European Union (EU-28) in the period of the recent economic crisis. The study exhibits a positive relationship between FDI and economic growth in EU28 starting with 2008. However, there are some countries for which higher FDI did not generate economic growth and some countries where higher GDP did not attract more FDI and FDI did not bring economic growth. The basic conclusion is that on overall in the European Union there was a mutual relationship between economic growth and FDI since the beginning of the crisis with a tendency of reducing disparities between countries in attracting FDI.

The most recent study was the research conducted by 
Reza et al (2018) which finds a causal relationship between Foreign Direct Investment Inflows (FDI) and Gross Domestic Product (GDP) Growth. The study also shows that the issue of Foreign Direct Investment (FDI) Inflows has become an essential weapon of Gross Domestic Product (GDP) growth for Bangladesh, bringing in technological development, capital investment and knowledge also needed for economic growth. According to this view, this paper aims at studying the relationship between FDI and economic growth in Bangladesh by the co-integration and Vector Error Correction Metrics (VECM) Test. The empirical analysis has conducted by employing annual secondary data for the year of 1990-2015 of Bangladesh, to investigate the relationship between FDI Inflows and Economic Growth in Bangladesh. Paper reveals the positive relationship running from FDI Inflows to GDP in the long-run and short-run. The study suggests that Bangladesh government can construct foreign investment-friendly policies, transfer of knowledge and trade promotion as well.

To summarize, it could be noticed that a huge amount of studies conducted to examine the relationship between FDI with economic growth, exportation, labour force, capital accumulation, advanced technologies, skills and economic policy. The majority of these studies demonstrate a positive relationship between FDI and economic growth in developing countries. In order to provide and explain the correlation between economic growth and FDI, panel data analysis and time series regression are utilised by numerous of these studies. Finally, the majority of the studies have used Gross Domestic Product for economic growth.

\section{RESEARCH METHODOLOGY}

\subsection{Data and Sample Selection}

The study performed the quantitative approach to investigate the impact of FDI on GDP in Iraq. The sample period consists of 10-year annual data for Iraq over the period 2006-2015. The reason behind selecting the sample period was that a ten-year period provides sufficient room for analysis. Variables used in the study are FDI net inflows as an independent variable and GDP as a dependent variable. The data for the variables under study was obtained from World Bank Database.

\subsection{Research Models}

The research applies secondary yearly time series data starting from 2006 to 2015. A starting point for interpreting time series data is checking for stationarity through utilizing unit root tests represented by ADF test. Then the study employs the OLS regression model for the estimation of regression. Furthermore, following quantitative model is used for simple linear regression analysis:

$$
G D P_{i}=\beta_{0}+\beta_{1} F D I_{i}+\mu_{i}
$$

Where:

- $\quad \boldsymbol{G D P}_{\boldsymbol{i}}$ represents Gross Domestic Product of Iraq;

- $\quad \boldsymbol{\beta}_{\mathbf{0}}$ is the intercept for the equation;

- $\quad \boldsymbol{F D I} \boldsymbol{I}_{\boldsymbol{i}}$ is Foreign Direct Investment Net Inflows in Iraq;

- $\quad \boldsymbol{\beta}_{1}$ is slope coefficient of Foreign Direct Investme;

- $\quad \boldsymbol{\mu}_{\boldsymbol{i}}$ represents error term for the equation;

The equation estimates the FDI on GDP. In order to check stationarity of the variables, unit root test (ADF) is utilized estimating the model. Firstly, the unit root test is conducted to determine whether the variables are stationary or non-stationary. Non-stationary variables can result in a spurious regression (Brooks, 2014). Findings obtained from non-stationary data may exhibit a relationship between variables, where an actual relationship does not exist. ADF test is applied as a unit root test for checking stationarity of the variables under study. When unit root test demonstrates that variables are stationary or $I(0)$, a normal OLS regression model can be estimated (Gujarati and Porter, 2008). By contrast, if variables are found to be non-stationary or I(1), Johansen test of cointegration must be developed to see if the linear combination of these variables is stationary. This task 
is performed to transform non-stationary data into stationary data in order that the consistent and reliable results can be achieved (Iordanova, 2015).

\subsection{Research Analysis and Sampling}

Descriptive statistical analysis, correlation and regression model (that represent OLS regression model) are employed by utilising Stata Software to analyse the secondary data acquired for Iraq which were obtained from World Bank Database.

\section{RESULTS AND INTERPRETATION}

\subsection{Results of unit root test (ADF)}

In case of Dickey Fuller test, a problem of autocorrelation maybe created. To tackle autocorrelation problem, Dickey and Fuller have developed a test named Augmented Dickey Fuller Test.

Using the abovementioned unit root test, the following hypotheses can be developed:

- Null Hypothesis $\left(H_{0}\right)$ : variable is not stationary or has a unit root

- $\quad$ Alternative Hypothesis $\left(H_{1}\right)$ : variable is stationary or does not have unit root

The unit root results are summarized in Table 1 . The time series unit root test for GDP explores that at level, the absolute value of the ADF test statistics (2.057) is less than the absolute value of $5 \%$ critical value (3.000); therefore, the null hypothesis cannot be rejected that exhibits the non-stationarity of time series data.

Since the data for GDP are non-stationary at level, the first differenced should be derived applying the same mentioned above test for checking stationarity. Consequently, at first differenced, the ADF test reveals that time series are stationary for the variable because the absolute value of test statistics (10.827) is bigger than the absolute value of 5 percent critical value (3.000).

To conclude, GDP is found to be non-stationary or $I(0)$ at level by utilizing the ADF test of checking stationarity; while the data turned into stationarity by taking the first difference.
Surprisingly, the result of FDI, as an independent variable, reveals the same result that the time series data are non-stationary at level using the ADF test since the absolute value of the ADF test statistics (1.384) is less than the absolute value of $5 \%$ critical value (3.000). Moreover, because of the nonstationarity of the variable FDI at level, the first differenced must be derived. Consequently, at first difference, the test reveals that time series turned to be stationary for the variable because the absolute value of test statistics (3.051) is greater than the absolute value of 0.05 critical value (3.000). In conclusion, at level, FDI is non-stationary; while at first difference, it is found to be stationary or $I(1)$ by applying the test of checking stationarity.

Finally, since all variables under study (GDP and FDI) are non-stationary at level utilizing the Augmented Dickey Fuller (ADF) unit root test while stationary at first difference, then Johansen test of co-integration must be run and developed.

Table 1: Unit Root Test Results Using the ADF Test

\begin{tabular}{|c|c|c|c|c|c|}
\hline \multirow{2}{*}{\multicolumn{2}{|c|}{$\begin{array}{l}\text { Part A } \\
\text { Method }\end{array}$}} & \multicolumn{2}{|c|}{ GDP } & \multicolumn{2}{|c|}{ FDI } \\
\hline & & $\begin{array}{c}\text { Test } \\
\text { Statistics }\end{array}$ & $\begin{array}{c}5 \% \\
\text { Critical } \\
\text { Value }\end{array}$ & $\begin{array}{c}\text { Test } \\
\text { Statistics }\end{array}$ & $\begin{array}{c}\% \\
\text { Critical } \\
\text { Value }\end{array}$ \\
\hline & level & $2.057-$ & -3.000 & -1.348 & -3.000 \\
\hline ADF & $\begin{array}{c}1^{\text {st }} \\
\text { Difference }\end{array}$ & -10.827 & -3.000 & -3.051 & -3.000 \\
\hline
\end{tabular}

\subsection{Analysis of the Long-run Relationship}

Because of the non-stationarity of the data for all variables under study at level while stationarity at first differenced, Johansen test of co-integration must be applied. Using the aforementioned co-integration test, the following hypotheses can be developed:

- $\quad H_{0}$ : There is no co-integration between Foreign Direct Investment and Gross Domestic Product.

- $\quad H_{1}$ : There is co-integration between Foreign Direct Investment and Gross Domestic Product.

Table 2: Johansen Test for Co-integration Results for the variables 


\begin{tabular}{ccc}
\hline \hline \multicolumn{3}{c}{ Johansen Test for Co-integration } \\
\hline $\begin{array}{c}\text { Maximum } \\
\text { Rank }\end{array}$ & Trace Statistic & $\begin{array}{c}5 \% \text { critical } \\
\text { value }\end{array}$ \\
\hline 0 & $6.6633^{*}$ & 15.41 \\
\hline 1 & 1.8948 & 3.76 \\
\hline \hline
\end{tabular}

As can be seen from Table 2, the results of Johansen Test for Co-integration, for the variable under study (FDI and GDP), reveals that the null hypothesis cannot be rejected because the trace statistic (6.6633) is less than $5 \%$ critical value (15.41); meaning that there is no long run relationship between GDP as dependent variable and FDI as independent variable and they do not move together and then there is no co-integration among the variables.

To conclude, since there is no co-integration or long run association between variables, Vector Error Correction Model (VECM) cannot be run rather the study can employ unrestricted VAR model to check for the short run relationship among variables under study.

\subsection{Analysis of the Short-run Relationship}

There are some tests that can be used to analyse the short-run relationship between variables under study:

\subsubsection{Vector Auto-Regressive Model (VAR)}

The Vector Auto-regression (VAR) model can be applied for analyzing data because it is considered to be one of the most flexible and effective models for the examination of multivariate time series. This model was presented into practical econometrics by Sims (1980). The model is a natural generalisation and an addition of the univariate autoregressive model to dynamic multivariate time series. The vector autoregression (VAR) model is confirmed to be very valuable for forecasting and for describing the dynamic behaviour of economic variables and financial time series and for forecasting. It often presents better forecasts than those from univariate time series models (Aga, 2014).

In general, the VAR models can be made conditional on potential future paths of specified variables and are often seen to provide a more flexible forecast. Additionally, in order to provide data description and forecasting, the VAR model could be employed for policy analysis and structural inference. Typically, the imposition convinced assumption about the causal structure of the data under investigation is vital to summarize the causal effects of innovations and unforeseen shocks on the variables in the model. Moreover, the word Vector derived from their own past, in general, it could use past values in order that it can predict future of variables in terms of Vector Autoregression model (Aga, 2014).

\subsubsection{Granger Causality Test}

The co-integration test verifies the long-term equilibrium relationship between variables. In addition, it will determine the form of the relationship. According to Studenmund (2006), Granger causality is a fact in which one series consistently changes before another series variable, and also testing for causality in both ways or directions through testing the hypothesis, if the F-statistic is significant, then the granger cause exist. Furthermore, this test is essential, because it gives us opportunity to analyse which series leads to the other series, as well as, such leading series variables are extremely beneficial for estimating purpose. The hypothesis of Granger causality is tested by the VAR model.

In order to apply Granger Causality Test, all chosen variables must be stationary. Moreover, the test can be employed dependent upon the number of lags chosen in VAR model. From the selection order criterion, 2 lags can be selected and the granger causality test can exhibit the following results:

Table 3: The Granger Causality Test Results for the variables

\begin{tabular}{ccc}
\hline \hline \multicolumn{3}{c}{ Granger Causality Test } \\
\hline Part A: Dependent variable dFDI & & \\
\hline $\begin{array}{c}\text { Est. } \\
\text { Coefficient }\end{array}$ & $\begin{array}{c}\text { Chi- } \\
\text { squared }\end{array}$ & $\begin{array}{c}\text { Prob. } \\
\text { Value }\end{array}$ \\
\hline
\end{tabular}




\begin{tabular}{|c|c|c|c|c|}
\hline dGDP & $\begin{array}{c}\text { Lag } \\
1 \\
\text { Lag } \\
2\end{array}$ & $\begin{array}{r}0.0105124 \\
-0.0034562\end{array}$ & 3.6586 & 0.161 \\
\hline \multicolumn{5}{|c|}{ Part B: Dependent variable dGDP } \\
\hline \multirow{3}{*}{ dFDI } & & $\begin{array}{c}\text { Est. } \\
\text { Coefficient }\end{array}$ & $\begin{array}{c}\text { Chi- } \\
\text { squared }\end{array}$ & $\begin{array}{c}\text { Prob. } \\
\text { Value }\end{array}$ \\
\hline & $\begin{array}{c}\text { Lag } \\
1 \\
\end{array}$ & 1.446637 & \multirow[t]{2}{*}{128.24} & \multirow[t]{2}{*}{0.000} \\
\hline & $\begin{array}{c}\text { Lag } \\
2\end{array}$ & -4.168316 & & \\
\hline
\end{tabular}

To start reporting the result of the test in table 3, we must consider two cases as there are two dependent variables; we have a pair of null and alternative hypotheses for each of the cases separately.

Firstly, the null hypothesis is that the lagged dGDP does not granger-cause dFDI versus the alternative hypothesis that is the lagged dGDP does grangercause dFDI. The guideline is: when the probability value is greater than 0.05 , we cannot reject the null hypothesis. In part (A), of table 3 shows that coefficients are statistically insignificant and the pvalue is (0.161) which is greater than 5 percent thus, null hypothesis cannot be rejected at five percent significance level. This allows us to conclude that lagged of the first difference of GDP does not grangercause the first difference of FDI.

Secondly, the null hypothesis is that the lagged dFDI does not granger-cause dGDP versus the alternative hypothesis that is the lagged dFDI does granger-cause dGDP. Moreover, in part (B) of table 3, we can see that the null hypothesis can be rejected due to the low $\mathrm{p}$ value which is $(0.000)$ that is less than 0.05 by far, meaning that the lagged of the first difference of FDI granger-causes the first difference of GDP. Furthermore, the results also show that coefficients are statistically significant. We can conclude that FDI Granger-Causes GDP and there is a short-run causality running from FDI to GDP. The magnitude of coefficients indicates that 1 percent increase in FDI has (1.45) percent positive impact on dGDP after one year. The concluding word is that, our data exhibits one-way
Granger Causality from FDI to GDP.

\subsection{Discussion of Results}

The research found that there is a relationship among Foreign Direct Investment and GDP Growth for Iraq with the help of annual time series secondary data commencing from 2006 to 2015. The Johansen Cointegration test analysis found that there is no longterm relationship between FDI and GDP; they do not move together and then there is no co-integration among the two variables. The results of the study are similar to the studies examined by Gupta and Singh (2016) for Russia and South Africa; and Aga (2014) for Turkey. On the other hand, the findings of the study are contrary to the studies conducted by Baig et al. (2016) for Pakistan, Nepal, Bhutan, India and Maldives; Gupta and Singh (2016) for Brazil, China and India; Baharumshah and Almasaied (2009) for Malaysia; Balamurali and Bogahawatte (2004) for Seri Lanka; Andraz and Rodrigues (2010) for Portugal and Reza et al (2018) for Bangladesh;

In the short run analysis, there is a unidirectional causal relationship between FDI and GDP; FDI granger causes GDP, meaning that there is a short-run causality running from FDI to GDP. The results of the research are in agreement with studies conducted by (Baig et al. (2016) in case of Nepal; Carlos and Eddie (2015) for China, but running from GDP to FDI; Seyoum et al. (2015) for three African countries (Egypt, Gabon, and Mauritania), whereas causality running from GDP growth to FDI in four African countries (Cote d'Ivoire, Kenya, South Africa and Zambia); Ozturk and Kalyoncu (2007) in the case of Pakistan but their study found that GDP granger causes FDI). By contrast, the findings of the study in terms of the short term causality was different to the study of Carlos and Eddie (2015) for Brazil, Mexico, Peru and South Korea which found no causal relationship between the two variables in the study for the four countries under study. Furthermore, some studies in the literature portrayed two-way Granger causality link between 
FDI and GDP, like: Balamurali and Bogahawatte (2004) for Seri Lanka; Jun (2015) for SAARC member countries; Ozturk and Kalyoncu (2007) for Turkey and Pakistan showed a positive bi-directional causality between FDI and economic growth in the case of Turkey.

Additionally, the results of the paper, regarding the direction of the relationship between FDI and GDP, is in accordance with the research conducted by Borensztein, Gregorio and Lee (1998) for 69 developing countries, the results exhibited positive relationship between FDI and GDP only when the host country has satisfactory absorptive competence and high level of educational sectors for progressive technologies; Bende-Nabebde (2001) for the ASEAN-5 countries found the positive significant impact of FDI on economic growth in Indonesia, Malaysia and Philippines; Marwah and Tavakoli (2004) for Indonesia, Malaysia, Philippines and Thailand; Zhang (2001) and Su and Liu (2016) for China; Chee and Nair (2010) for Asia-Oceania region; Trojette (2016) for the MENA region revealed that FDI positively affects Economic Growth for 14 of the 19 countries in MENA region; Jude and Levieuge (2014) for 94 developing countries confirm a non-linear positive effect of FDI on economic growth through supporting an institutional development. On the other hand, the results of the study is in disagreement with Borensztein, Gregorio and Lee (1998) which revealed that those countries which have low level of education sectors and low level of human capital their growth rate is negatively related with FDI; Audi (2011) for seven south Mediterranean countries (Turkey, Jordan, Syria, Algeria, Egypt, Morocco, and Tunisia); BendeNabebde (2001) for the ASEAN-5 countries in case of Singapore and Thailand; Trojette (2016) for 5 of the 19 countries in the sample (Algeria, Iraq, Lebanon, Libya and West Bank and Gaza) and the reason for finding the negative effects of FDI on GDP in those countries go back to the high level of corruption and other forms of cronyism; Jude and Levieuge (2014) finds that FDI alone has a negative or, at best, a non-significant effect on growth.

\section{CONCLUSION AND RECOMMENDATION}

\subsection{Conclusion}

This research investigated the impact of Foreign Direct Investment on Gross Domestic Product in Iraq for 10 years starting from 2006 to 2015. The paper used Foreign Direct Investment as independent variable of the study; while Gross Domestic Product as a dependent variable of the research.

First of all, the research applied the Unit Root Test represented by ADF test for checking the stationarity for the data used in the study. The results revealed that the two variables under study were non-stationary at level, while after taking the first differences, they turned into stationary. Then Johansen Test for Cointegration was run to check for the long-term relationship between variables. The findings of the test demonstrated that there is no long run relationship among variables under study, meaning that there is no co-integration among variables and in the long run they do not move together.

Moreover, findings of the Granger causality Wald tests revealed that FDI granger-causes GDP it also found a short-run causality running from FDI to GDP. The results of the study indicated a positive impact of dFDI on dGDP after one year. The concluding word is that, the data of the research exhibits one-way Granger Causality running from FDI to GDP.

\subsection{Recommendation}

The study recommended the following:

- Specific policies should be developed to provide a friendly legislative environment and reductions in taxes for foreign investors and reduce the barriers for capital flows so that investors can invest their capital in Iraq to promote its growth further.

- Iraqi policies should follow key points like increasing private contribution and superior openness and competitiveness, an attractive tax 
system and a modern infrastructure to attract more FDI to flow into Iraq.

- It is recommended that Iraq has to pay more attention to improve the level of education sectors and financial sector and to empower human capital. It also has to decrease lending rate, transportation and instability terms of political and economic environment as well as to improve liberalized market environment.

- It is recommended that Iraqi government should bring reforms in the domestic market to attract more FDI to Iraq.

\section{REFERENCES}

1. Abdul Khaliq \& Ilan Noy, (2007). Foreign Direct Investment and Economic Growth: Empirical Evidence from Sectoral Data in Indonesia. Working Papers 200726, University of Hawaii at Manoa, Department of Economics.

2. Abu - Eideh, O. M. (2014). Impact of Foreign Direct Investment on Economic Growth in Palestine: An Econometric Study of the Period (1994-2013). European Journal of Business and Management. 6(21), pp. 61-88.

3. Acaravci, A., \& Ozturk, I. (2012). Foreign direct investment, export and economic growth: Empirical evidence from new EU countries. Romanian Journal of Economic Forecasting, 2, pp. 52-67.

4. Aga, A. A. Kh. (2014). The Impact of Foreign Direct Investment on Economic Growth: A Case Study of Turkey 1980-2012. International Journal of Economics and Finance. 6(7), pp. 71-84.

5. Agrawal, G., \& Khan, M. A. (2011). Impact of FDI on GDP: A Comparative Study of China and India. International Journal of Business and Management, 6(10), pp. 71-79. http://dx.doi.org/10.5539/ijbm.v6n10p71.

6. Ahmed, T., \& Malik, S. U. (2012). Determinants of inflow of foreign direct investment (FDI) into Pakistan. NICE Research Journal, 5, pp. 93-110. Online available at: http:/ / ssrn.com/abstract $=2183074$

7. Alfaro, L., Chanda, A., Kalemli-Ozcan, S., \& Sayek, S. (2004). FDI and Economic Growth: The Role of Local Financial Markets. Journal of International Economics, 64(1), pp.89-112.

8. Andraz, J., \& Rodrigues, P. (2010). What causes economic growth in Portugal: exports or inward FDI? Journal of Economic Studies, 37(3), pp. 267-287.

9. Arisoy, I. (2012). The impact of foreign direct investment on total factor productivity and economic growth in Turkey. The Journal of Developing Areas, 46(1), pp. 17-29. doi.org/10.1353/jda.2012.0013.

10. Asaad, Z. (2014). The Economic Determinants of Foreign Direct Investment Inward to Iraq for Period (2004-2011). Journal of the University of Duhok, 17(1), pp. 192-217.
11. Audi, M. (2011). Is foreign direct investment a cure for economic growth in developing countries? Structural model estimation applied to the case of the south shore Mediterranean countries, Journal of International Business and Economics, 11(4), pp. 32-51.

12. Baharumshah, A. Z., \& Almasaied, S. W. (2009). Foreign direct investment and economic growth in Malaysia: interactions with human capital and financial deepening. Emerging Markets Finance and Trade, 45(1), 90102. http://dx.doi.org/10.2753/REE1540496X450106.

13. Baig, M. M., Kiran, S., \& Bilal, M. (2016). Relationship between FDI and GDP: A Case Study of South Asian Countries. Journal of Business and Financial Affairs. 5(3), pp. 1-4

14. Balamurali, N., \& Bogahawatte, C. (2004). Foreign Direct Investment and Economic Growth in Sri Lanka. Sri Lankan Journal of Agricultural Economics, 6(1), pp. 37-50.

15. Balasubramanyam, V., Salisu, M., \& Sapsford, D. (1996). FDI and Growth in EP and IS Countries. The Economic Journal. 106(434), pp. 92-105. Online Available at: https://www.jstor.org/stable/2234933?seq=1\#page_sc an_tab_contents.

16. Bende-Nabebde, A., Ford, J., \& Slater, J. (2001). FDI, Regional Economic Integration and Endogenous Growth: Some evidence from Southeast Asia. Pacific Economic Review. 6(3), pp. 383-399. https://doi.org/10.1111/1468-0106.00140.

17. Bengoa, M., \& Sanchez-Robles, B. (2003). FDI, economic freedom and growth: new evidence from Latin America. European Journal of Political Economy, 19(3), pp. 529-545, https://doi.org/10.1016/S0176-2680(03)00011-9.

18. Borensztein, E., De Gregorio, J., \& Lee, J. W. (1998). How does foreign direct investment affect economic growth? Journal of International Economics. 45(1), pp. 115-135. Online available at: https://olemiss.edu/courses/inst310/BorenszteinDeG Lee98.pdf

19. Brahim, M., \& Rachdi, H. (2014). Foreign Direct Investment, Institutions and Economic Growth: Evidence from MENA Region. Journal of Reviews on Global Economics, 3, pp. 328-339.

20. Brooks, C. (2014). Introductory Econometrics for Finance. 3rd ed. United Kingdom: Cambridge University Press. Available online at: https:// www.academia.edu/25000363/Introductory_E conometrics_for_Finance_3th_Ed.

21. Carkovic, M., \& Levine, R. (2005). Does Foreign Direct Investment Accelerate Economic Growth? Onlie available at: https://www.piie.com/publications/chapters_previe w/3810/08iie3810.pdf

22. Carlos, E. F., \& Eddie, V. Z. (2015). Foreign direct investment and gross domestic product growth. International Conference on Applied Economics, ICOAE 2015, 2-4 July 2015, Kazan, Russia. Procedia Economics and Finance, 24 (2015), pp.198 - 207. Online available 
https://core.ac.uk/download/pdf/82198912.pdf

23. Carson, C. S. (2003). International Monetary Fund: Foreign Direct Investment Trends and Investment. Online available at: https://www.imf.org/external/np/sta/fdi/eng/2003 ८102803.pdf

24. Chee, Y. L., \& Nair, M. (2010). The Impact of FDI and Financial Sector Development on Economic Growth: Empirical Evidence from Asia and Oceania. International Journal of Economics and Finance, 2(2), pp. 107-119

25. Cheema, S. A. (2013). Investing in Iraq: Prospects and Challenges. Centre for West Asian Studies. Jamia Millia Islamia - New Delhi India, Middle East Institute. Online available at: http://www.mei.edu/content/investingiraq-prospects-and-challenges.

26. Chen, C., Chang, L., \& Zhang, Y. (1995). The Role of Foreign Direct Investment in China's Post 1978 Economic Development. World Development 23(4), pp. 691-703. Online available at: https://www.sciencedirect.com/science/article/abs/ pii/0305750X9400143M.

27. Choe, J. I. (2003). Do Foreign Direct Investment and Gross Domestic promote Economic Growth? Review of Development Economics, 7(1), pp. 44-57. https://doi.org/10.1111/1467-9361.00174.

28. Fitzová, H., \& Žídek, L. (2015). Impact of Trade on Economic Growth in the Czech and Slovak Republics. Economics \& Sociology, 8(2), pp. 36-50, doi: 10.14254/2071-789x.2015/8-2/4

29. Gujarati, D. N. \& Porter, D. C. (2008). Basic Econometrics. 5th ed. New York: McGraw-Hill/Irwin.

30. Gupta, P., \& Singh, A. (2016). Causal nexus between foreign direct investment and economic growth: A study of BRICS nations using VECM and Granger causality test. Journal of Advances in Management Research, 13(2), pp. 179-202.

31. Investopedia Dictionary, online available at: http://www.investopedia.com/terms/f/financialperf ormance.asp\#ixzz4fru4IJbZ.

32. Iordanova, T. (2015). Introduction to Stationary and Non-Stationary Processes. Available online at: http://www.investopedia.com/articles/trading/07/st ationary.asp. Date of access: 17 September. 2019.

33. Jude, C., \& levieuge, G. (2014). Growth Effect of FDI in Developing Economies: the Role of Institutional Quality. Laboratoire d'Economie d'Orléans, 40(4), pp. 1-31. https://doi.org/10.1111/twec.12402.

34. Jun, S. (2015). The Nexus between FDI and Growth in the SAARC Member Countries, Journal of East Asian Economic Integration, 19(1), pp. 39-70.

35. Lahiri, S. \& Ono, Y. (1998). Foreign Direct Investment, Local Content Requirement and Profit Taxation. Economic Journal, 108(447), pp. 444-457. Online available at:

https://www.jstor.org/stable/2565571?seq=1\#page_sc an_tab_contents.

36. Li, X., \& Liu, X. (2005). Foreign direct investment and economic growth: an increasingly endogenous relationship, World Development, 93(3), pp. 393-407, doi: 10.1016/j.worlddev.2004.11.001.

37. Lloyds bank, (2019). Foreign Direct Investment in Iraq. Online available at https://www.lloydsbanktrade.com/en/marketpotential/iraq/investment

38. Marwah, K., \& Tavakoli, A. (2004). The Effects of Foreign Capital and Imports on Economic Growth: further evidence from four Asian countries (1970-1998). Journal of Asian Economics, 15(2), pp. 399-413.

39. Nicet-Chenaf, D., \& Rougier, E. (2009). FDI and growth: A new look at a still puzzling issue, Groupe de Recherche en Economie Théorique et Appliquée, Vol. 5113, No. 200913, pp. 1-26.

40. Ozturk, I., \& Kalyoncu, H. (2007). Foreign direct investment and growth: An empirical investigation based on cross-country comparison. Munich Personal RePEc Archive. Paper No. 9636, 60(1), pp. 75-82. Online available at: https://mpra.ub.unimuenchen.de/9636/1/MPRA_paper_9636.pdf

41. Reza, S. M., Fan, H., Reza, T., \& Wang, B. (2018). The impact of foreign direct investment inflows on economic growth: evidence from Bangladesh. Journal of Business and Retail Management Research (JBRMR), 12(2), pp. 212223. DOI: 10.24052/JBRMR/V12IS02/TIOFDIIOEGEFB

42. Seyoum, M., Wu, R., \& Lin, J. (2015). Foreign Direct Investment and Economic Growth: The Case of Developing African Economies. Social Indicators Research: An International and Interdisciplinary Journal for Quality-of-Life Measurement. 122 (1), pp.45-64.

43. Simionescu, M. (2016). The relation between economic growth and foreign direct investment during the economic crisis in the European Union. Journal of Economics and Business. 34(1), pp. 187-213. Online available at: https://papers.ssrn.com/sol3/papers.cfm?abstract_id $=2803140$.

44. Studenmund, A. H. (2006). Using Econometrics: A Practical Guide (5th ed.). Dary Fox.

45. Su, Y., \& Liu, Z. (2016). The impact of foreign direct investment and human capital on economic growth: Evidence from Chinese Cities, China Economic Review, 37 (2016), pp. 97-109. https://doi.org/10.1016/j.chieco.2015.12.007.

46. Trojette, I. (2016). The Effect of Foreign Direct Invest on Economic Growth: The Institutional Threshold. Région et Développement, 43, pp. 111-138.

47. Umoh, O. J., Jacob, A. O., \& Chuku, C. A. (2012). Foreign Direct Investment and Economic Growth in Nigeria: An Analysis of the Endogenous Effects. Current Research Journal of Economic Theory, 4(3), pp. 53-66.

48. UNCTAD (2018) World Investment Report, Investment and New Industrial Policies. Country Fact Sheet: Iraq. Online available at: https://unctad.org/sections/dite_dir/docs/wir2018/ wir18_fs_iq_en.pdf

49. Urata, S. (1998). Japanese foreign direct investment in Asia: Its impact on export expansion and technology 
acquisition of the host economies. Waseda University and Japan Center for Economic research. National Library of Australia.

50. Wang, J., \& Blomström, M. (1992). Foreign Direct Investment and Technology Transfer: A Simple Model. European Economic Review. 36(1), pp. 137-155. https://doi.org/10.1016/0014-2921(92)90021-N.

51. http://www.webuildiraq.org/business-iraq/foreigninvestment-in-iraq/

52. Wing, J. (2013). 2011 Sees Another Large Increase In Foreign Investment In Iraq. AK News, available at https://www.mei.edu/publications/investing-iraqprospects-and-challenges.

53. Zhang, K. H. (2001). Does foreign direct investment promote economic growth? Evidence from East Asia and Latin America. Contemporary Economic Policy, 19(2), 175-185. http://dx.doi.org/10.1111/j.14657287.2001.tb00059.x. Online available at: https://onlinelibrary.wiley.com/doi/abs/10.1111/j.14 65-7287.2001.tb00059.x 